\title{
Estimating the Number of Walruses in Svalbard from Aerial Surveys and Behavioural Data from Satellite Telemetry
}

\author{
CHRISTIAN LYDERSEN, ${ }^{1,2}$ JON AARS ${ }^{1}$ and KIT M. KOVACS ${ }^{1}$
}

(Received 8 January 2007; accepted in revised form 16 August 2007)

\begin{abstract}
All known terrestrial haul-out sites for walruses in Svalbard $(\mathrm{n}=79)$ were surveyed during the period 1-3 August 2006 , and sites that were in use $(n=17)$ were documented using digital photography. A total of 657 walruses were counted on land in the resultant images. An extensive behavioural data set from walruses equipped with satellite relay data loggers, covering August 2002 to August 2005, was used to account for walruses that were in the water. The proportion of walruses at sea during the survey was calculated to be 0.750 on the basis of 28 thirty-day periods from 23 male walruses. Time of day and wind chill did not significantly affect haul-out behaviour. However, a logistic regression model revealed both a correlation among haul-out patterns of individuals within years, and a year effect $\left(\chi^{2}=6.42, \mathrm{df}=2, p=0.04\right)$. Because the survey was not flown in a year when satellite tags were deployed, the interannual variance was retained in a model (with no other explanatory variables). The overdispersion parameter from this model was $2.02($ deviance $=28.33, \mathrm{df}=14)$. Thus, variance in proportions of time individuals spent at sea was multiplied by this parameter to achieve a corrected SE around the estimate. The 95\% CI based on this SE corresponded to a proportion of walruses at sea during the survey between 0.717 and 0.781 , resulting in an estimated total number of walruses in Svalbard in August 2006 of 2629 (95\% CI: 2318-2998).
\end{abstract}

Key words: walrus, Odobenus rosmarus, aerial survey, digital photography, satellite telemetry, haul-out behaviour, Svalbard

RÉSUMÉ. Toutes les échoueries terrestres de morses connues à Svalbard $(\mathrm{N}=79)$ ont été étudiées pendant la période allant du $1^{\text {er }}$ au 3 août 2006, et les échoueries utilisées $(\mathrm{N}=17)$ ont été documentées à l'aide de photographies numériques. En tout, 657 morses ont été dénombrés dans les images résultantes. Une série de données exhaustives sur le comportement des morses dotés d'enregistreurs de données par satellite - données portant d'août 2002 à août 2005 - a permis de faire le compte des morses se trouvant dans l'eau. La proportion de morses à la mer pendant la période visée par l'étude a été calculée à 0,750 sur la base de 28 périodes de trente jours à partir de 23 morses mâles. Le moment de la journée et le refroidissement éolien n'ont pas exercé une grande incidence sur le comportement en échouerie. Cependant, un modèle de régression logistique a révélé une corrélation entre les tendances en échouerie d'individus en dedans de plusieurs années, ainsi qu' un effet année ( $\left.\chi^{2}=6,42, \mathrm{dl}=2, p=0,04\right)$. Puisque l'étude n'a pas été effectuée au cours d'une année où les étiquettes satellites ont été déployées, l'écart interannuel a été conservé dans un modèle (sans aucune autre variable indépendante). Le paramètre de surdispersion découlant de ce modèle était de 2,02 (déviance $=28.33, \mathrm{dl}=14$ ). Par conséquent, l'écart en proportions de temps que les individus passaient en mer a été multiplié par ce paramètre pour obtenir une erreur-type corrigée autour de l'estimation. L'IC de $95 \%$ en fonction de cette erreur-type correspondait à une proportion de morses en mer pendant l'étude s'échelonnant entre 0,717 et 0,781, ce qui a donné un nombre total estimé de morses de 2629 à Svalbard en août 2006 (IC de $95 \%$ : 2318 - 2998).

Mots clés : morse, Odobenus rosmarus, étude aérienne, photographie numérique, télémétrie par satellite, comportement en échouerie, Svalbard

Traduit pour la revue Arctic par Nicole Giguère.

\section{INTRODUCTION}

Walruses (Odobenus rosmarus) in Svalbard, Norway, became protected in 1952 (Anonymous, 1952). At that time, these once numerous marine mammals had been exposed to 350 years of unregulated harvest, which had brought them to the brink of extinction (Norderhaug, 1969). Born (1984) summarized observations of walruses in the Svalbard area from 1954 to 1982 and concluded that the summering stock was about 100 animals, and that walrus numbers had increased since 1970. In 1993, a total of 741 walruses were observed in Svalbard, as calculated from maximum numbers of animals counted at various haul-out sites during fixed-wing and ground surveys performed from August to October (Gjertz and Wiig, 1995). As suggested by Born (1984), and later confirmed by satellite tracking (Wiig et al., 1996) and genetic studies (Andersen et al., 1998), the walruses in Svalbard are part of a larger, common Svalbard-Franz Josef Land population, in which most of the males summer in Svalbard and most females

\footnotetext{
${ }^{1}$ Norwegian Polar Institute, N-9296 Troms $\varnothing$, Norway

${ }^{2}$ Corresponding author: Lydersen@npolar.no

(C) The Arctic Institute of North America
} 


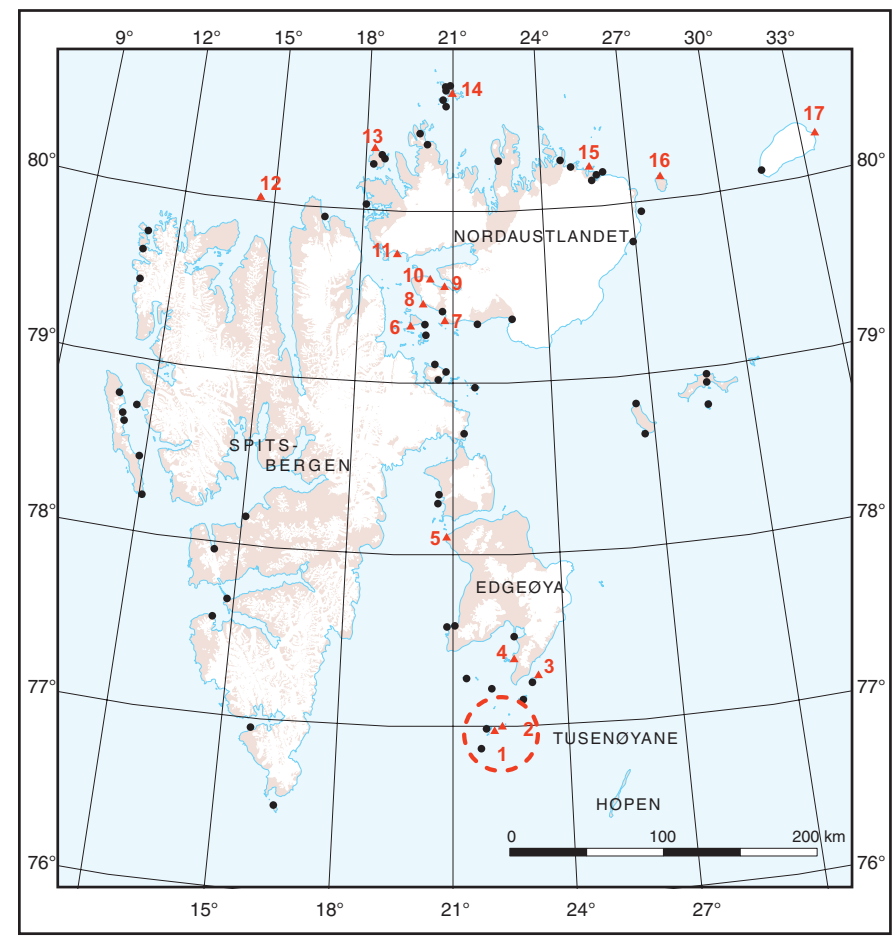

FIG. 1. Map of Svalbard showing haul-out sites for walruses that were visited during the aerial survey in August 2006. Triangles represent haul-out sites being used during the survey, and circles represent haul-out sites that were not in use. Numbers refer to the sites listed in Table 1. The Tusenøyane area is within the red dotted circle.

and calves remain in the Franz Josef Land area. On the basis of this fact, and assuming an equal sex ratio, Gjertz and Wiig (1995) suggested that this shared population consisted of a minimum of 1450 walruses older than two years plus an unknown number of calves. These reports supported the general impression from an increasing number of sightings of walruses at an increasing number of haul-out sites in Svalbard (Norwegian Polar Institute's (NPI) Fauna and Marine Mammal Sighting Databases) that this population was recovering. No systematic survey has been conducted since the early 1990s, and no attempt has been made in previous surveys to correct the numbers to account for animals in the water.

The purpose of the present study was to estimate the number of walruses in Svalbard during the ice-free summer period by (1) counting walruses on land at all known haul-out sites using aerial digital-photographic images and 2) developing a model based on the analysis of behavioural data collected from satellite relay data loggers to account for walruses in the water.

\section{MATERIAL AND METHODS}

\section{Aerial Survey}

The aerial digital-photographic survey was conducted on 1-3 August 2006. All known terrestrial haul-out sites for walruses were inspected from a helicopter flying at about $300 \mathrm{~m}(\sim 1000 \mathrm{ft})$. These included both sites currently in use and historical sites identified by Gjertz and Wiig (1994), unpublished reports held by the Governor of Svalbard's Environmental Division, NPI's Fauna Database and Marine Mammal Sighting Database, and extensive coastal boat surveys conducted in 2002-04 (Fig. 1). If walruses were present at a haul-out site, they were easily observed from this altitude, and digital photographs were taken of the hauled-out groups of animals (Nikon D2X and AF Nikkor 80-200 Zoom 1:2.8). Pictures were taken at a shutter speed of $1 / 500$ second or faster to avoid blur induced by helicopter movement. A total of 79 haul-out sites were inspected (Fig. 1). In addition to visiting the known haul-out sites, observers on both sides of the helicopter were constantly watching for hauled-out walruses when flying along the coastline between these sites. The total distance covered during the survey was approximately $4000 \mathrm{~km}$.

\section{Haul-out Behaviour from Satellite Telemetry}

Custom-designed satellite relay data loggers (SRDLs), developed specifically for walrus deployments in collaboration with the Sea Mammal Research Unit (SMRU), University of St. Andrews, Scotland, were used to collect data on the time walruses spent in the water versus the time they spent hauled out (Fig. 2). The basic software and hardware in these SRDLs were the same as in previous SRDLs deployed by the SMRU (Fedak et al., 2002) except that they had no speed or temperature sensors. The electronics were embedded in epoxy and encased in a stainless steel housing (a tube $10 \mathrm{~cm}$ long $\times 6 \mathrm{~cm}$ in diameter, weighing approximately $0.8 \mathrm{~kg}$, Fig. 2) to give the electronics maximum protection, and then the casings were flooded with polyurethane. At each end of the tag, at the base towards the tusk, there was an extension of the steel housing $(2 \times 3 \mathrm{~cm})$. Each extension had a hole for a small screw, which went a few millimetres into the tusk to prevent the tag from shifting position; each extension also had a small rim at its terminus that prevented the hose clamps that went over the extensions and held the tag to the tusk from slipping off. A ridge of stainless steel that protruded around the top surface of the tag provided protection for the antennae and sensors (see Fig. 2). Two holes were drilled through this ridge so that sediment, slush or other debris would be flushed away (Fig. 2). Because the protective ridge is only on the front side of the tag and the antennae and the sensors should be pointing upwards, the tag can be deployed on only one side of the animal, in this case the left tusk. Each tag had an identification number welded onto its surface (see Fig. 2, number 7) to enable future recognition if the animal carrying the tag was resighted.

This study used all parts of the tags' sampling protocols relevant to haul-out behaviour to create correction factors. The SRDLs continually monitor the data their sensors are 

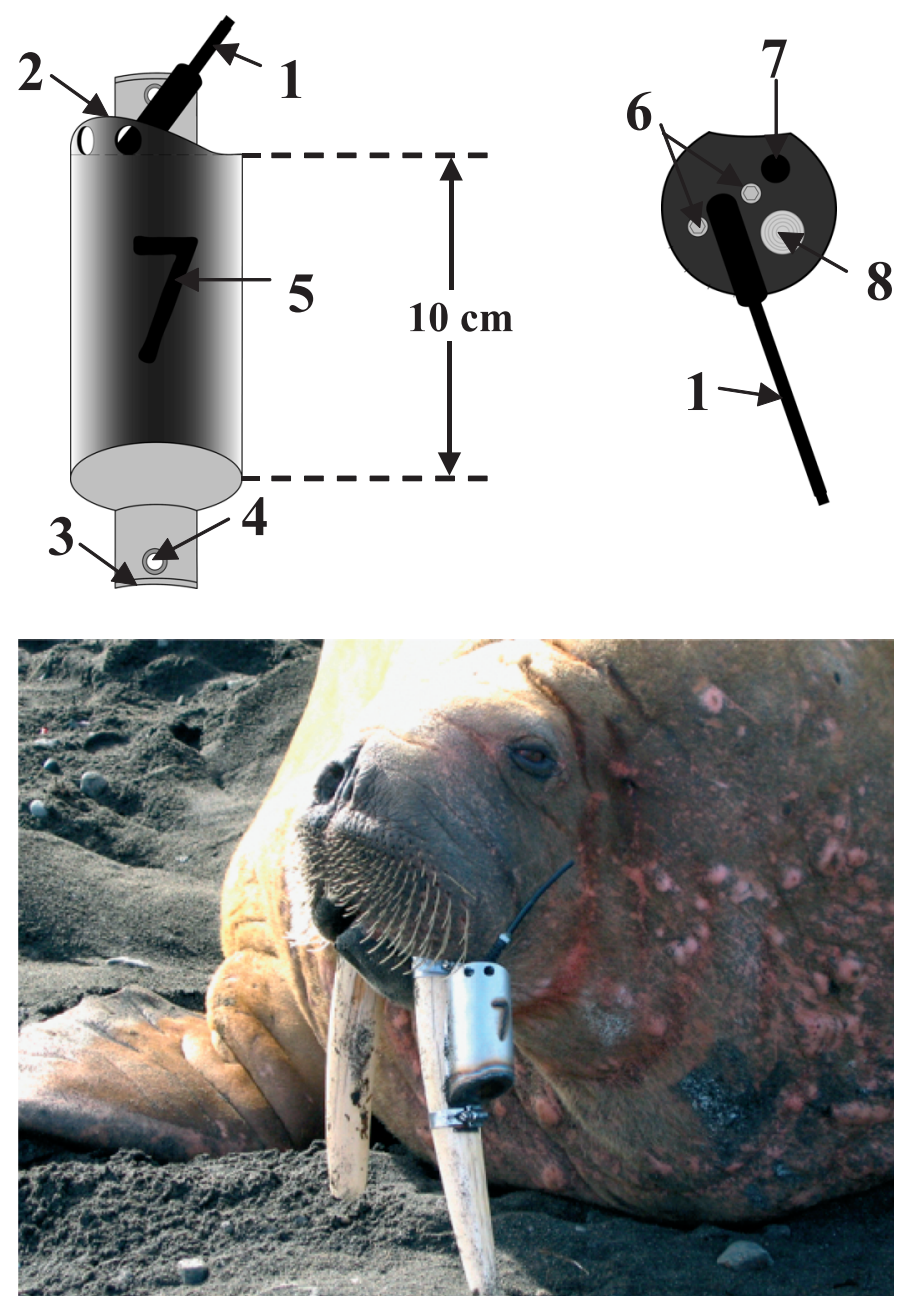

FIG. 2. Custom-made satellite relay data loggers (SRDLs) that were mounted on walrus tusks, developed in collaboration with the Sea Mammal Research Unit, University of St. Andrews, Scotland. Upper left panel: front view; upper right panel: top view; bottom panel: SRDL mounted on a walrus. 1: antennae; 2: protective ridge; 3 : small rim to prevent hose clamp to slide off; 4 : hole for screw; 5: individual tag ID number; 6 : salt-water switch; 7 : communication port for PC; 8: pressure transducer.

collecting (surface sensor, depth sensor, and time interactions) and group the animals' activities into three different states: diving, hauled out, and at surface. A walrus is identified as diving when it is below a preset depth, in this case $6 \mathrm{~m}$. Behaviour is classified as hauled out when the tag has been dry for at least 10 minutes, and this state ends when wet-dry sensors indicate wet for more than $40 \mathrm{sec}$ onds. A walrus at surface is neither diving nor hauled out, i.e., the animal enters this state when it remains above the depth threshold for diving but is not dry long enough to be classified as hauled out.

Summary statistics, with exact start points and duration to the minute of time spent in each of these three states, are constructed for every six-hour time period and transmitted via the Argos satellite system (Toulouse, France). For this study, only the contrast between "not hauled out" (i.e., diving or at surface) and "hauled out" was of interest. Unfortunately, not all of the six-hour summary statistics are received through the Argos system for a variety of reasons, such as satellite availability at the time of transmission, the animal's surface behaviour, and proximity to other competing Argos devices. For this study, however, behavioural information could be filled in for almost all of the periods for which summary statistics were missing. This was possible because the haul-out events recorded by a SRDL were given consecutive numbers. Thus, unaccounted-for time surrounded by haul-outs with consecutive numbers cannot be time spent hauled out, which means the animal must have been in the water, either at the surface or diving. In addition, in the rare cases for which there are no summary statistics and haul-out events are missing (as revealed by non-consecutive numbers of these events), dive information is often available, and the dive time and extended surface periods between dives can be used to fill in some of the gaps in the record.

During August 2002-04, a total of 23 adult male walruses were equipped with these newly developed walrus SRDLs. The animals were immobilized with an intramuscular injection of etorphine $\mathrm{HCl}$ that was reversed with diprenorphine $\mathrm{HCl}$, as described by Griffiths et al. (1993). As soon as a drugged animal showed signs of the influence of the etorphine $\mathrm{HCl}$, the reversal agent was injected. The tag was then mounted to the left tusk using HI-TORQUE ${ }^{\text {TM }}$ heavy-duty stainless steel hose clamps (JCS Hi-Torque Ltd., Suffolk, England) and Sicaflex epoxy. Two small holes were drilled in the tusk. A screw with a smaller diameter than the hole was placed into each hole, with its head secured under the hose clamp, to prevent the tag from sliding. The whole deployment process took $2-3 \mathrm{~min}$. The animal was then rolled onto its belly, and a soft silicon endotracheal tube (20 mm diameter, $90 \mathrm{~cm}$ long, Cook Inc. Bloomington, Indiana, USA) was inserted into the trachea and connected to the Zodiac boat pump via a custom-made transition tube. Thus the walrus was kept breathing artificially until the diprenorphine $\mathrm{HCl}$ took effect and the animal was breathing again without support. No mortality was experienced when using this intubation technique. All animal handling protocols used were approved by the Norwegian Animal Research Authorities and the Governor (Sysselmannen) on Svalbard.

\section{Correction Factors}

To create a correction factor that would account for walruses in the water during the survey, we used a data set of haul-out behaviour recorded for each walrus $(n=23)$ during a 30-day period starting the day after tagging. (The 30 days started $24 \mathrm{~h}$ after drugging in order to reduce potential bias in behaviour due to drug effects.) Some of the SRDLs gave haul-out information for more than a year, and for those animals $(n=5)$ the period $1-30$ August in the following year was also included in the analyses. This procedure resulted in 30-day haul-out records for 6 individuals in 2002, 9 in 2003, 11 in 2004, and 2 in 2005 (see Fig. 3).

Our statistical analyses were conducted using the $\mathrm{R}$ suite of statistical software (R Development Core Team, 


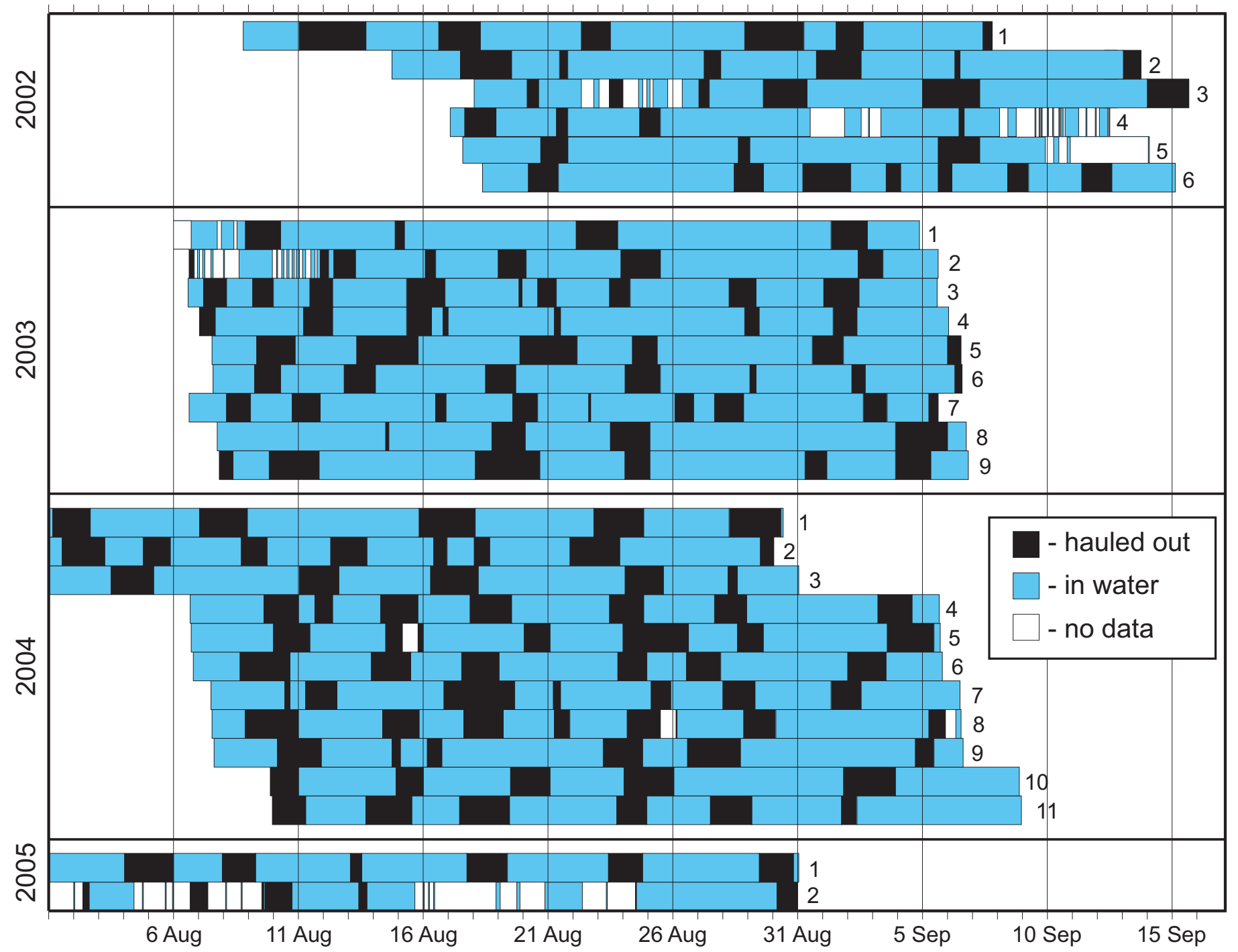

FIG. 3. Haul-out chronologies for 28 walrus data sets based on information from satellite relay data loggers (SRDLs) deployed on the tusks of the animals in August 2002 to 2004. For SRDLs that transmitted for more than one year (walruses 1, 2, and 3 in 2004, and 1 and 2 in 2005), we included haul-out information from the first 30 days of deployment, starting $24 \mathrm{~h}$ after drugging, in addition to haul-out data from the 30 first days of August the following year. The figure illustrates that within each year, walruses that were tagged at the same time tend to be hauled out (and thus also at sea) at the same time more frequently than would be expected by chance.

2007). We tested whether there was a diurnal pattern in haul-out behaviour by comparing the time of day (h) for the start and the termination (in two different analyses) of each haul-out period to the expected distribution (uniform, generated by the command "runif" in R with identical sample size) if no time-of-day effect was present. The statistical comparison was performed using the Kolmogorov-Smirnov test in R (command "ks.test"). Haulout events were sufficiently spread in time to be treated as independent of one another for this analysis.

Weather effects on the proportion of animals hauled out at a particular time were explored using logistic regression models. The haul-out patterns of individuals are autocorrelated by virtue of being a time series. Thus, we explored weather effects on haul-out events that were sufficiently separated in time to avoid time dependence. The length of this period was chosen using the autocorrelation function (acf) in R (Venables and Ripley, 1999:405). Figure 4 shows that, on average, there is no correlation to the previous haul-out state after five days. Thus, all potential effects of weather were explored using data from the first hour every fifth day. Wind chill effects were explored through a logistic regression model run in $\mathrm{R}$, using the binomial proportion of tagged animals as the response variable. For the wind chill analysis, only the nine walruses tagged in 2003 were used. These animals were tagged on Tusenøyane, $90 \mathrm{~km} \mathrm{W-NW}$ of Hopen Island (Fig. 1), and they generally remained in the vicinity for the first 30 days after tagging. Hopen Island has a meteorological station where data on wind speed $\left( \pm 0.1 \mathrm{~ms}^{-1}\right)$ and temperature $\left( \pm 0.1^{\circ} \mathrm{C}\right)$ are collected four times per day; we used one record daily, taken at $0100 \mathrm{~h}$. The data on temperature and wind were combined into a wind chill factor $\left(\mathrm{T}_{\mathrm{wc}}=13.112+0.6215 \mathrm{~T}_{\mathrm{a}}-11.37 \mathrm{~V}^{0.16}+0.3965 \mathrm{~T}_{\mathrm{a}} \mathrm{V}^{0.16}\right.$, 


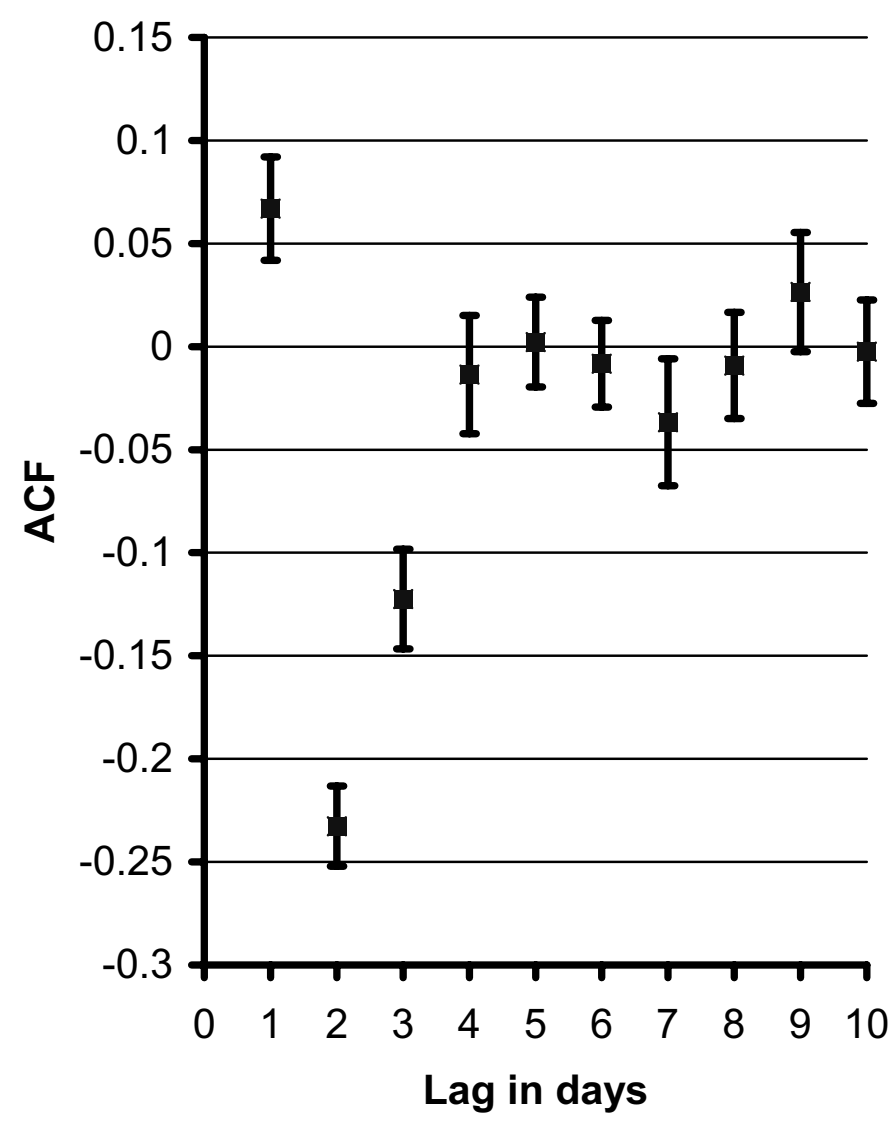

FIG. 4. The average autocorrelation $(\mathrm{ACF} \pm 95 \% \mathrm{CI})$ for the 28 thirty-day periods of walrus haul-out behaviour (haul-out is given a value of 0 ; at sea, a value of 1 ), with time lags of 1 to 10 days.

where $\mathrm{T}_{w c}$ is the wind chill, $\mathrm{V}$ is the wind speed in $\mathrm{km} \mathrm{h}^{-1}$, and $\mathrm{T}_{\mathrm{a}}$ is the ambient air temperature in ${ }^{\circ} \mathrm{C}$, http:// www.nws.noaa.gov/om/windchill/index.shtml). The input to this model for behavioural state was based on whether an animal was hauled out or in the water during the first minute of each hour within the data set.

The population-specific haul-out fraction was calculated simply as the average proportion of time spent hauled out across the 30 days of records, and the remainder was the proportion of time spent at sea, which was needed to correct for the number of walruses not hauled out during the survey.

\section{Estimating the Total Number of Walruses}

One digital picture from each haul-out where walruses were present was selected and used to count the number of animals at each site. Counting was performed by three independent readers, and all three counts for each site were identical. Walruses are large animals, and even though they haul out in dense groups, they are easily counted from pictures taken directly above the group, especially given the enlargement possibilities with digital images. Since no diurnal or weather effects were found, the proportion of walruses expected to be in the sea (pSea) during the survey was assumed to be the average for all 28 of the 30-day
TABLE 1. Numbers of walruses counted from digital pictures at the haul-out areas during an aerial survey in Svalbard in August 2006. (Numbers in parentheses refer to the site numbers in Fig. 1).

\begin{tabular}{lc}
\hline \hline Haul-out Area & Number of Walruses \\
\hline Slettholmen (1) & 133 \\
Havmerra (2) & 34 \\
Halvmåneøya (3) & 1 \\
Andretangen (4) & 125 \\
Kapp Lee (5) & 24 \\
Wahlbergøya (6) & 14 \\
Augustabukta (7) & 4 \\
Svartneset (8) & 31 \\
Palandervågen (9) & 13 \\
Ytre Palanderbukta (10) & 3 \\
Narkvaløya (11) & 9 \\
Moffen (12) & 11 \\
Lågøya (13) & 37 \\
Isflakbukta (14) & 10 \\
Kapp Brunøya (15) & 31 \\
Storøya (16) & 110 \\
Kræmerpynten (17) & 67 \\
Total & 657 \\
\hline \hline
\end{tabular}

periods from the tagged walruses. The proportion hauled out would then be 1-pSea). The estimated number of animals in the sea is thus the number counted on the digital pictures multiplied by $\mathrm{pSea} /(1-\mathrm{pSea})$. But a correction factor that adjusted for the uncertainty due to overdispersion of the data (residual deviance/residual degrees of freedom; Venables and Ripley, 1999) was used to incorporate uncertainty into the estimate. Uncertainty either arose from environmental factors that we tested for, but failed to correlate significantly to haul-out data because of limited statistical power, or was due to other factors not recorded, such as dependence between individuals. Year effects were explored using data from 2002, 2003, and 2004, since data were available from only two individuals in 2005. Again, only data from the first hour each fifth day were used.

\section{RESULTS}

Walruses occupied 17 of the 79 haul-out sites visited during the survey (see Fig. 1). The number of animals at these sites ranged from 1 to 133 individuals (Table 1). A total of 657 walruses were counted on land at the haul-out sites.

Haul-out behaviour data were not complete for the whole 30-day period for all 28 records (Fig. 3). However, the mean fraction of this time for which the SRDLS did achieve data coverage was very high (0.96 \pm SD 0.09; range $0.63-1$ of the total time), and for 18 of the 28 records the coverage was $100 \%$. The average duration of haul-out periods was $29.8 \mathrm{~h}(\mathrm{SD}=14.7 \mathrm{~h}$, range $2-68 \mathrm{~h})$, and the corresponding values for the at-sea periods were $85.6 \mathrm{~h}$ $(\mathrm{SD}=44.7 \mathrm{~h}$, range $5-236 \mathrm{~h})$. No evidence of diurnal effects on haul-out pattern were found for the tagged walruses during the 30-day period studied when comparing onset $(\mathrm{n}=203$, D-value $=0.059, p=0.87)$ or termination $(\mathrm{n}=194, \mathrm{D}$-value $=0.057, p=0.91)$ of haul-out 
periods to random samples with uniform distributions (with equal $\mathrm{n}$ ) using the Kolmogorov-Smirnov test. Likewise, wind chill was not found to have an effect (logit(prop. haul-out $)=-1.725\left(\right.$ SE 0.549) $+0.053\left(\right.$ SE 0.066), $\chi^{2}=$ $1.15,1 \mathrm{df}, p=0.28)$. The range in weather parameters experienced by the animals included in this test was $-0.4-$ $8.0^{\circ} \mathrm{C}$, and $0-12.3 \mathrm{~ms}^{-1}$. The ranges in the same parameters around the archipelago during the aerial survey-based on data from eight weather stations, Hopen, Edgeøya, Hornsund, Sveagruva, Longyearbyen (Svalbard airport), Ny Ålesund, Verlegenhuken, and Karl XII- øya-were only slightly different, ranging from 1.2 to $8.6^{\circ} \mathrm{C}$ and from 1.0 to $7.4 \mathrm{~ms}^{-1}$.

Because haul-out proportions were not influenced by wind chill or time of day, we based the estimate of the proportion of animals at sea during the survey on the average proportion of the 28 August records. This average was 0.750 . The variance of $\log$ (prop. in sea/[1 - prop. in sea]) was 0.106 . However, the walruses did not haul out randomly (Fig. 3); correlation in haul-out patterns existed among individuals. Walruses tagged at the same time exhibited some synchronicity in their subsequent haul-out patterns, though they rarely hauled out together again at a same site despite the temporal similarity in their haul-out behaviour (Fig. 5). This pattern was revealed by the overdispersion parameter from a logistic regression model with no explanatory variables (i.e., the full model was simply $\log [$ prop. in sea/( 1 - prop. in sea $)]=$ intercept; over-dispersion parameter $=2.02($ deviance $=28.33, \mathrm{df}=$ $14)$ ). Some of this over-dispersion was due to a weak year effect $\left(\chi^{2}=6.42,2 \mathrm{df}, p=0.04\right)$ within the model. The observed average proportions of time at sea were 0.777 $($ range $=0.689-0.876)$ in 2002, $0.779($ range $=0.697-$ $0.840)$ in 2003, and 0.712 (range $=0.668-0.763)$ in 2004 . For the two individuals from 2005 that were not included in the test, this proportion was 0.742 (range $=0.729$ $0.755)$. Because the survey was conducted in a year without telemetry data, the deviance accounted for by year was not removed from the model. The variance in individual (logit transformed) time at sea (0.106) was multiplied by the over-dispersion parameter (2.02) to achieve a corrected standard error (0.088) around the estimate. The 95\% CI based on this parameter corresponded to a proportion between 0.717 and 0.781 of time spent at sea.

The number of walruses counted on land was 657 . The number of walruses at sea estimated on the basis of this count was 1972 (95\% CI: 1661-2341). The sum of these numbers gives the estimated number of walruses in Svalbard in August 2006 as 2629 (95\% CI: 2318-2998).

\section{DISCUSSION}

This walrus survey was conducted in August primarily because this is the period of the year when coastal waters in the Svalbard area are most likely to be ice-free. However, this was also the period for which the most behavioural information was available from satellite tagging records to model the correction factors. Even walruses equipped with SRDLs that had moved out of the Svalbard area for periods of the year (i.e., during the breeding season) had all returned to the archipelago before August (C. Lydersen and K. Kovacs, unpubl. data). In August 2006, the northern pack-ice edge was situated far north of Svalbard, at about $82^{\circ} \mathrm{N}$. In this area, the ocean floor at that latitude is located at $4000-5000 \mathrm{~m}$ depth, and thus this ice edge is unlikely to serve as a haul-out location for walruses. Walruses are shallow divers (e.g., Gjertz et al., 2001) that feed on benthic invertebrates. In addition, during August 2006 the annual sea ice had all melted or drifted away from the archipelago, giving the walruses no alternatives for hauling out except their terrestrial sites.

One of the basic assumptions for this survey was that all walruses that were hauled out in Svalbard during the time of the survey were counted. Observer biases, which can be a problem during visual aerial surveys, especially for animals like walruses that tend to congregate in large, dense groups (Udevitz et al., 2005), were nonexistent in this survey since counts were made directly from digital photographs. Because of the large size of walruses and the magnification and manipulation options possible when using high-resolution digital pictures, potential reader biases were found not to be a problem. One can never be $100 \%$ certain that every hauled-out group of animals was visited during the survey, but our extensive pre-survey ground-truthing and the fidelity generally shown by walruses to traditional haul-out sites make it very likely that the 79 sites visited during the survey represent all of the currently used potential walrus haul-out sites in Svalbard. Additionally, during the $4000 \mathrm{~km}$ of survey flying, most of which was along beaches and other types of coastlines with continuous observation from the aircraft, no "new" sites were discovered.

Another factor that can certainly affect the accuracy of a walrus survey is the availability of alternative haul-out platforms (i.e., sea ice) in the survey area. An attempt to perform this survey was made in August 2005, but the survey was aborted because large areas in the southeast of Svalbard contained vast fields of loosely packed annual ice floes. Even though the actual ice cover was low (1$2 \%$ ), the ice created thousands of potential resting platforms, and the walruses clearly preferred hauling out on the ice to hauling out on land. The area in the southeast of Svalbard where almost all the walruses of Gjertz and Wiig (1995) and about 5\% of those in the present study were counted had no animals hauled out on terrestrial sites at all when surveyed in August 2005. It is of course possible to survey walruses when sea ice is present. However, a survey design involving line transects or strip surveys (Borchers et al., 2002) would be required, and the uncertainties in the counts would be much greater.

Haul-out behaviour data in this study include information only for the part of the year pertinent to the aerial survey. During this time interval, the animals spent $75 \%$ of 
their time at sea and 25\% hauled out. Several previously published studies on walrus behaviour have documented comparative information on haul-out patterns from either satellite telemetry or time-depth recorders (TDRs) (Born and Knutsen, 1997; Gjertz et al., 2001; Jay et al., 2001; Born et al., 2003, 2005; Acquarone et al., 2006). TDRs provide complete time series of haul-out behaviour, while data from satellite tags generally have gaps in the timestring either because the instruments are set to a duty cycle or because not all of the information collected by the tags is received by the Argos system. Unfortunately, few authors quantify the latter data issue in publications. Therefore, only TDR data will be compared here to the current study, in which the SRDLs had close to $100 \%$ data coverage (96\%). Gjertz et al. (2001) deployed three TDRs on walruses in Svalbard that collected data for 9-19 days. They reported that the average at-sea time was $56 \mathrm{~h}$ followed by an average of $20 \mathrm{~h}$ hauled out on land, which corresponds to spending $74 \%$ of the time in the water. Jay et al. (2001) equipped four Pacific walruses (O.r. divergens) with TDRs that collected data for 29-36 days. These walruses spent $77 \%$ of the recorded time in the water. Acquarone et al. (2006), who deployed TDRs that collected data for 5-15 days on six walruses in Greenland, found that these walruses spent $67 \%$ of their time in the water, a somewhat smaller percentage than was reported in the two other studies. However, some short records of this small sample could have over-estimated haul-out time if they reported total time of tag deployment, since walruses take some time to recover from drugging. All of these studies were conducted on adult male walruses during late summer (August-September), and all report remarkably consistent proportions of time spent hauled out on land versus time at sea, which are similar to the proportions documented in this study. For whatever reason(s), walruses seem to be quite consistent across their geographic range in spending about $25 \%$ of their time out of the water, at least during late summer. Additional information supporting the consistency of this behaviour pattern for walruses can be found in a study of sleep in captive walruses, in which four two-year-old walruses were videotaped continuously for 7-17 days in a pool filled with seawater and equipped with a resting platform. The four youngsters spent an average of $75 \%$ of their time in the water (Pryaslova and Lyamin, 2006).

Haul-out patterns of the walruses in this study were not significantly affected by ambient temperature or wind speed (or a wind chill factor). But our power to detect a difference is very weak because the sample size for the data subset used in this analysis was small. Additionally, the available weather data are not ideal, in that they were collected from a station about $90 \mathrm{~km}$ away from where the instrumented animals were hauled out. This factor is not likely to be a large problem, however: the specific haul-out sites in Tusen $\varnothing y$ ane where the animals were tagged in 2003 consist of small, flat islands that create little shelter from winds in any direction, so there is no reason to assume that conditions there are very different from those at Hopen, where the meteorological data were measured.

The lack of a wind chill effect was somewhat surprising because temperature and wind speed are often found to affect haul-out behaviour in various pinniped species, including the walrus. A study by Born and Knutsen (1997) reported that walruses in their study area abandoned the beach altogether during very bad weather (rain and strong winds up to $20 \mathrm{~ms}^{-1}$ ). They found a significant correlation between wind chill and numbers of hauled-out animals (1989: $-3.0^{\circ}-8.0^{\circ} \mathrm{C}$ and $0-4.5 \mathrm{~ms}^{-1} ; 1990:-1.8^{\circ}-14.3^{\circ} \mathrm{C}$ and $0->20 \mathrm{~ms}^{-1}$ ) in one of the two study years (1990), but no correlation was found in the less extreme wind year.

There are probably several reasons why weather parameters affect the haul-out behaviour of pinnipeds, but the most obvious is their need to maintain thermal balance. Large animals like walruses have a surface-to-volume ratio that is advantageous for heat retention, and their highly gregarious haul-out behaviour leads to a reduction of exposed surfaces, which further lessens heat loss in cold weather (Fay and Ray, 1968). If air temperatures fall to levels at which the animals would have to increase circulation to the skin to avoid tissue damage from freezing (Lydersen et al., 1994), they would likely be induced to enter the water, where the temperature would be higher and conditions more stable. However, the range of weather conditions experienced by the walruses in the present study was not dramatic (temperature: $-0.4^{\circ}-8.0^{\circ} \mathrm{C}$; wind speed: $0-12.3 \mathrm{~ms}^{-1}$ ), which is likely the reason that these parameters did not influence the behaviour of the animals. These conditions, typical for August in Svalbard, are another reason for conducting surveys at this time of the year, since they mean low variability in haul-out behaviour of the animals and provide good flying conditions.

Weather conditions might affect haul-out behavior of walruses not only for purely physiological reasons, but also via increased alertness or nervousness related to the difficulty of detecting terrestrial predators when wind noise is high or visibility is poor. However, the only potential terrestrial predator of walruses in Svalbard is the polar bear (Ursus maritimus), and generally this predator does not attack adult male walruses. In fact, all-male walrus groups on Svalbard seem to ignore polar bears even when they approach quite closely (Gjertz, 1990; personal observation).

No diurnal pattern was found in the haul-out behaviour of walruses in Svalbard during August-September. Diurnal patterns in haul-out behaviour in pinnipeds are often linked to day versus night variations in temperature, light regimes, or other environmental variables such as tides, which make it more profitable to haul out under certain conditions. In polar regions, higher air temperatures may make hauling out more energetically profitable, and better visibility could increase the chances of detecting a terrestrial predator. Many pinnipeds have diurnal patterns that are influenced by the behaviour of their prey; some fish and invertebrates move up or down in the water column diurnally, making 
them easier to catch at certain times of the day. During August Svalbard experiences a $24 \mathrm{~h}$ sunlight regime, although some resident pinniped species in this area still exhibit diurnal haul-out patterns even under these light conditions (e.g., Reder et al., 2003; Carlens et al., 2006). However, walruses should have no problems with thermoregulation under the conditions experienced in late summer, and their main prey are more or less sessile benthic invertebrates (Fay, 1981; Gjertz and Wiig, 1992) that are probably just as easy to find at any time of day, so diurnal patterns in haul-out behaviour would not be expected for these animals at this time of year. Another point in this context is that most of the haul-out periods registered were longer than $24 \mathrm{~h}$, which suggests a lack of diurnal rhythmicity. Although duration of haul-out periods for the walruses in Svalbard was highly variable, the average length was $29.8 \mathrm{~h}$. Average haul-out periods longer than $24 \mathrm{~h}$ were also found for walruses in Greenland ( $38 \mathrm{~h}$; Born and Knutsen, 1997) and in Alaska (41 h; Jay et al., 2001).

Haul-out behaviour of walruses in Svalbard and elsewhere almost certainly changes with season and with environmental factors over longer time scales, and perhaps diurnal patterns are exhibited at other times of year, but across a few weeks in late summer, no such patterns were seen. Thus a simple population average of time spent at sea could be used to adjust survey numbers to create a total estimate. The uncertainty around the estimate reflects interannual variances in haul-out proportions and the existence of some social synchronicity in haul-out behaviour (also see below). One important factor to note with respect to the correction factor used in this study is that it is based on haul-out behaviour of adult males only. Females and calves might have quite different haul-out patterns; they might have to rest on land more frequently for longer or shorter periods than adult males. Because most of the walruses summering in Svalbard are adult males, the correction factor used here likely provides a quite reasonable estimate for this subpopulation, but it might be inaccurate for regions where female and calf haul-outs are more common.

The temporal pattern seen among individual animals that were marked together in this study suggested some sort of synchronicity in the pattern of haul-out behaviour. Walruses are gregarious mammals that haul out together, so this was not unexpected. What was surprising, however, was that when spatial information was incorporated into the analyses (Fig. 5), it was found that over the long term, the "groups" marked together hauled out at similar times, but not necessarily at the same place. Thus, the synchronicity was not due to the group's travelling together at sea when foraging and returning to land together, but reflected a stereotypical pattern that included an at-sea bout of approximately $86 \mathrm{~h}$ followed by about $30 \mathrm{~h}$ hauled out on land, with groups of animals remaining "in phase."

The total number of walruses estimated to inhabit Svalbard during August 2006 was 2629 (95\% CI: $2318-$ 2998). Born (1984) suggested that there had been an increase in walrus numbers in Svalbard between 1970 and the early 1980s, and there are many recent indications

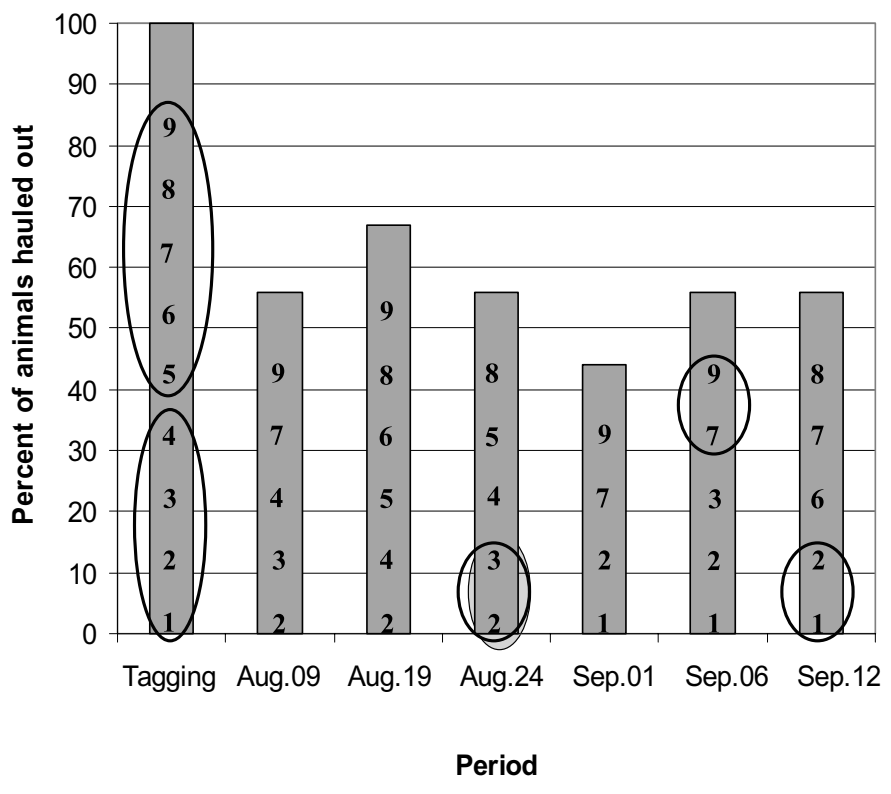

FIG. 5. Spatial and temporal haul-out patterns for nine walruses equipped with satellite relay data loggers on 5-6 August 2003. Numbers in the bars represent individual animals. The walruses were initially tagged at two adjacent haul-outs $5 \mathrm{~km}$ apart (walruses 1-4 at Slettholmen; walruses 5-9 at Havmerra). The figure depicts the proportion of these walruses that were hauled out at six later dates. The dates are not random; they were chosen as the dates when the most individuals in this group were simultaneously hauled out, in order to see how the animals were distributed spatially with respect to one another. Circles indicate individuals tagged at the same haul-out site that were later found to be hauled out simultaneously at another site.

(e.g., more animals observed on terrestrial haul-outs, more haul-out sites being used, more frequent observations of females and calves within the Svalbard area) that they have been increasing steadily since that time. However, it is not straightforward to quantify the rate of this potential increase with the data that are available. The most comprehensive previous survey of walruses in Svalbard, conducted in 1993 (Gjertz and Wiig, 1995), compiled maximum observed numbers near and on haul-out sites, but it did not attempt to correct for animals not counted. Another issue with this earlier survey was that it took place over a period of time long enough for animals from various haul-outs to have moved between sites and perhaps to be counted twice. The time between the surveys of the two largest groups of walruses in 1993 was 12 days. When walruses decide to move, they can cover long distances relatively quickly. Two tracks from walruses equipped with SRDLs in this study were measured to be $849 \mathrm{~km}$ during $248 \mathrm{~h}$ (10.3 days) and $942 \mathrm{~km}$ during $327 \mathrm{~h}$ (13.6 days), respectively (C. Lydersen and K. Kovacs, unpubl. data). These measurements correspond to average horizontal surface speeds of $82 \mathrm{~km} \mathrm{day}^{-1}$ and $69 \mathrm{~km} \mathrm{day}^{-1}$, suggesting that walruses could swim from the southernmost to the northernmost terrestrial haul-out in Svalbard in about a week. In the 2006 study, the whole of Svalbard was surveyed in less than three days, so this source of error was minimized.

If we take the highest number of walruses observed by Gjertz and Wiig (1995) within a limited time frame to exclude potential double counting, they counted 657 
walruses in the period from 23 to 26 August 1993. Of these walruses, an estimated 120 were in the water close to the haul-out sites and 537 were on land. Using this number for comparison with our count, ignoring various uncertainties, the rate of increase in walruses in Svalbard from 1993 to 2006 would be only $1.6 \%$ per year (from 537 to 657 in 13 years). Witting and Born (2005) reviewed population parameters for walruses and found a finite growth rate of $7 \%$ per year for a population in a phase of growth under favourable environmental conditions with no food limitations. Such conditions are thought to prevail in Svalbard, so we are at a loss to explain the slow estimated growth rate. Our estimate of population growth is incomplete, however, in that we are enumerating only the subpopulation summering in Svalbard, not the whole population living across the northern Barents Sea. A complete survey of the known population range would be useful for management purposes.

In summary, 2629 (95\% CI: 2318 -2998) walruses were estimated to be present in the Svalbard area during August 2006. Since the walruses in this area are predominantly males and are only part of a common Svalbard-Franz Josef Land population, it is reasonable to assume that this population as a whole numbers more than 5000 animals. This population is completely protected from hunting, there are no known interactions with fisheries, and the pollution levels are too low to cause mortality or any impediment to reproduction (Wolkers et al., 2006). The scarce data available for comparisons suggest that the Svalbard-Franz Josef Land walrus population has been increasing over the last two decades, but at a rate that is lower than expected.

\section{ACKNOWLEDGEMENTS}

This project was funded by the Norwegian Research Council and the Norwegian Polar Institute. We thank Vidar Bakken, Heinrich Eggenfellner, Mike Fedak, Dave Griffiths, Andreas Haga, Colin Hunter, Hans Lund, and Sofie van Parijs for help in the field, and Rory Beaton, Mike Fedak, Colin Hunter, and Phil Lovell for help with the development and manufacture of the SRDLs. We also thank Audun Igesund and Jan Roald for help with the figures. We thank Rolf Anker Ims, Audun Stien, and Nigel Yoccoz for statistical advice. Special thanks are extended to the Governor of Svalbard (Sysselmannen) for helicopter support, and to Oddvar Instanes and Alf Tørrisplass (Airlift) for their extraordinary efforts in the pilot seats, which allowed us to conduct this survey in a timely fashion.

\section{REFERENCES}

ACQUARONE, M., BORN, E.W., and SPEAKMAN, J.R. 2006. Walrus (Odobenus rosmarus) field metabolic rate measured by the doubly labeled water method. Aquatic Mammals 32: 363-369.

ANDERSEN, L.W., BORN, E.W., GJERTZ, I., WIIG, Ø., HOLM, L.-E., and BENDIXSEN, C. 1998. Population structure and gene flow of the Atlantic walrus (Odobenus rosmarus rosmarus) in the eastern Atlantic Arctic based on mitochondrial DNA and microsatellite variation. Molecular Ecology 7:1323-1336.

ANONYMOUS. 1952. Fredning av hvalross (Protection of walruses). Kongelig Resolusjon (Royal Decree) 20. juni 1952 (In Norwegian). Available from Fiskeridepartementet, Øvre Slottsgate 2, P.O.B. 8188 Dep., 0032 Oslo, Norway.

BORCHERS, D.L., BUCKLAND, S.T., and ZUCCHINI, W. 2002. Estimating animal abundance: Closed populations. London: Springer-Verlag.

BORN, E.W. 1984. Status of the Atlantic walrus Odobenus rosmarus rosmarus in the Svalbard area. Polar Research 2:27-45.

BORN, E.W., and KNUTSEN, L.Ø. 1997. Haul-out and diving activity of male Atlantic walruses (Odobenus rosmarus rosmarus) in NE Greenland. Journal of Zoology, London 243:381-396.

BORN, E.W., RYSGAARD, S., EHLME, G., SEJR, M., ACQUARONE, M., and LEVERMANN, N. 2003. Underwater observations of foraging free-living Atlantic walruses (Odobenus rosmarus rosmarus) and estimates of their food consumption. Polar Biology 26:348-357.

BORN, E.W., ACQUARONE, M., KNUTSEN, L.Ø., and TOUDAL, L. 2005. Homing behaviour in an Atlantic walrus (Odobenus rosmarus rosmarus). Aquatic Mammals 31:23-33.

CARLENS, H., LYDERSEN, C., KRAFFT, B.A., and KOVACS, K.M. 2006. Spring haul-out behavior of ringed seals (Pusa hispida) in Kongsfjorden, Svalbard. Marine Mammal Science 22:379-393.

FAY, F.H. 1981. Walrus Odobenus rosmarus (Linnaeus, 1758). In: Ridgway, S.H., and Harrison, R.J., eds. Handbook of marine mammals. Vol. 1. The walrus, sea lions, fur seals and sea otter. London: Academic Press. 1-23.

FAY, F.H., and RAY, C. 1968. Influence of climate on the distribution of walruses, Odobenus rosmarus (Linnaeus). I. Evidence from thermoregulatory behavior. Zoologica 53:1 - 18 .

FEDAK, M., LOVELL, P., McCONNELL, B., and HUNTER, C. 2002. Overcoming the constraints of long range radio telemetry from animals: Getting more useful data from smaller packages. Integrative and Comparative Biology 42:3-10.

GJERTZ, I. 1990. Do polar bears prey on walruses in Svalbard? Fauna 43:54-56. (In Norwegian with English summary).

GJERTZ, I., and WIIG, Ø. 1992. Feeding of walrus Odobenus rosmarus in Svalbard. Polar Record 28:57-59.

- 1994. Past and present distribution of walruses in Svalbard. Arctic 47:34-42.

- 1995. The number of walruses (Odobenus rosmarus) in Svalbard in summer. Polar Biology 15:527-530.

GJERTZ, I., GRIFFITHS, D., KRAFFT, B.A., LYDERSEN, C., and WIIG, Ø. 2001. Diving and haul-out patterns of walruses Odobenus rosmarus on Svalbard. Polar Biology 24:314-319.

GRIFFITHS, D., WIIG, Ø., and GJERTZ, I. 1993. Immobilization of walrus with etorphine hydrochloride and Zoletil. Marine Mammal Science 9:250-257.

JAY, C.V., FARLEY, S.D., and GARNER, G.W. 2001. Summer diving behavior of male walruses in Bristol Bay, Alaska. Marine Mammal Science 17:617-631.

LYDERSEN, C., HAMMILL, M.O., and KOVACS, K.M. 1994. Activity of lactating ice-breeding grey seals, Halichoerus grypus, 
from the Gulf of St. Lawrence, Canada. Animal Behaviour 48:1417-1425.

NORDERHAUG, M. 1969. Hvalrossens (Odobenus rosmarus) forekomst i Svalbardområdet 1960-1967. Norsk Polarinstitutts Årbok. 146-150. (In Norwegian).

PRYASLOVA, J., and LYAMIN, O. 2006. Behavioral sleep in the walrus. Sleep (Journal of Sleep and Sleep Disorders Research) 29, Abstract Supplement: A37-A38.

R DEVELOPMENT CORE TEAM. 2007. The R Project for statistical computing. www.r-project.org.

REDER, S., LYDERSEN, C., ARNOLD, W., and KOVACS, K.M. 2003. Haul-out behaviour of High Arctic harbour seals (Phoca vitulina vitulina) in Svalbard, Norway. Polar Biology 27:6-16.

UDEVITZ, M.S., JAY, C.V., and CODY, M.B. 2005. Observer variability in pinniped counts: Ground-based enumeration of walruses at haul-out sites. Marine Mammal Science 21: $108-120$.
VENABLES, W.N., and RIPLEY, B.D. 1999. Modern applied statistics with S-Plus. New York: Springer Verlag.

WIIG, Ø., GJERTZ, I., and GRIFFITHS, D. 1996. Migration of walrus (Odobenus rosmarus) in the Svalbard and Franz Josef Land area. Journal of Zoology, London 238:769-784.

WITTING, L., and BORN, E.W. 2005. An assessment of Greenland walrus populations. International Council for the Exploration of the Sea (ICES) Journal of Marine Science 62:266-284.

WOLKERS, H., VAN BAVEL, B., ERICSON, I., SKOGLUND, E., KOVACS, K.M., and LYDERSEN, C. 2006. Congenerspecific accumulation and patterns of chlorinated and brominated contaminants in adult male walruses from Svalbard, Norway: Indications for individual-specific prey selection. Science of the Total Environment 370:70-79. 